\title{
A Review on Compressive Strength of Concrete Containing Waste Cathode Ray Tube Glass as Aggregates
}

\author{
Nurul Noraziemah Mohd Pauzi \\ Faculty of Engineering and Science, Curtin University Sarawak, Miri, Malaysia; nurul.noraziemah@curtin.edu.my \\ Correspondence: nurul.noraziemah@curtin.edu.my/nurulnoraziemah@gmail.com
}

SUBMITTED: 22 September 2021; REVISED: 14 October 2021; ACCEPTED: 15 October 2021

\begin{abstract}
The issue of the cathode ray tube (CRT) technology facing its end-of-time and increasing quantities across the globe has acquired the responsiveness of many researchers. The use of waste CRT glass as a construction material has fascinated them due to its significant advantage in recycling the hazardous and non-biodegradable waste CRT glass. However, lack of knowledge about the effects and features of CRT glass as a construction material could be a hindrance to the excessive utilization of waste CRT glass. Therefore, in order to establish the idea of using CRT waste glass as a more common construction material, this paper reviews several recycling techniques of CRT glass and further detail on the workability, density, and compressive strength properties of concrete and mortar using CRT glass (treated or untreated) as fine aggregates. The review showed that, generally, the use of CRT glass as a complete or partial replacement of natural sand shows a slight increase in density, workability, and concrete strength compared to conventional concrete. However, there are no clear trends that can be concluded as this review also showed that various factors influenced its performance, such as percentage replacement, particle size, lead $(\mathrm{Pb})$ content, and types of admixtures.
\end{abstract}

KEYWORDS: Cathode ray tube; waste glass; lead; concrete, strength

\section{Introduction}

Over the last few years, the amount of electronic waste (e-waste), especially CRT, has been on the rise and it has become an emerging concern in many developing countries. Through a global perspective review, the increasing amount of e-waste in the coming years is due to the rapid advances in information technology and the increase in market demand for electronic equipment [1-4]. Generally, CRT technology can be found in old television sets, computer monitors, video cameras, video game machines, automated teller machines, radar displays, and oscilloscopes. But, advances in electronic technology have led to the continuous replacement of CRTs by new technologies, such as Plasma Display Panels (PDPs) and Liquid Crystal Displays (LCDs) [5,6]. The replacement of CRT technology has caused an increase in CRT waste. In China in 2012, an estimated 74 million old TV sets and 190 million computer monitors were obsolete due to CRT technology, and the figures are expected to rise in the coming years [1]. The increment of CRT waste can also be seen in Thailand, as in 2004, 750 thousand tons of discarded CRTs were recorded, whilst in 2010, the amount increased to about 1.05 million [7]. Other than that, Rocchetti et al. [8] estimated that in Europe, about 50 thousand to 150 thousand tons of CRT waste are collected and then treated every year and that number 
is expected to increase in the year ahead. Previous studies have shown that the amount of CRT waste has increased year by year and is expected to increase in the future. Yoshida et al. [2] claim that the highest generation of waste CRT technology is from the years 2015 to 2020 . Meanwhile, Zhao et al. [9] expect a drastic increase in the amount of CRT disposed of in the year 2050, as it is expected to be 6 times higher than in 2013. The increasing amount of CRT's waste has become a world concern as the mismanagement of this waste can create a serious impact on the environment. It is because CRT glass consists of heavy metals, especially the high concentration of lead $(\mathrm{Pb})$ metals $[1,7,10]$. According to Singh et al. [1], CRT is made of $85 \%$ glass that can be divided into three parts that are $65 \%$ of the glass is namely as panel glass, $30 \%$ as funnel glass and the remaining $5 \%$ is neck glass.

The neck part of the CRT contains the highest concentration of lead oxide $(\mathrm{PbO})$, which is a maximum of $39 \%$ and a minimum level of $34 \%$. Meanwhile, the funnel CRT glass contained $\mathrm{PbO}$ in amounts ranging from around $25 \%$ to $16 \%$. The $\mathrm{Pb}$ metals contained in the funnel glass are used to protect the audience from the radioactivity of the electron gun, as the $\mathrm{Pb}$ metals help to eliminate X-ray radiation $[11,12]$. Thus, as the panel part of the CRT does not contain any electron guns, it explains the lower percentage of $\mathrm{PbO}$ at only $4 \%$. Meng et al. [13] estimated that around $1.2 \mathrm{~kg}$ of Pb metal is distributed in one unit of the CRT monitor. On the other hand, it is found that inside the panel CRT glass, it contains a high concentration of barium oxide $(\mathrm{BaO})$ and strontium oxide $(\mathrm{SrO})$, about $7 \%$ to $11 \%$ and $9 \%$ to $17 \%$, respectively. It is due to the panel glass, which must be colourless. Lead-silicate glass is a brown colored glass, while barium-strontium silicate glass is transparent under the exposure of X-ray radiation. The issue of the high content of hazardous metals, especially $\mathrm{Pb}$, and the increasing amount of waste CRT glass has attracted attention from various parties.

Past studies considered the CRT glass as hazardous waste because it contains heavy metals $(\mathrm{Pb}, \mathrm{Ba}, \mathrm{Sr}$, etc.) and the concentration of toxic elements in the leachate exceeds the allowable limit. Hence, it should not be disposed of in landfill sites without proper treatment as it has the potential to cause damage in the aspects of acidification, abiotic depletion, and global warming. Besides, it can also harm the human body. For that reason, the recycling of CRT waste glass is necessary since it helps preserve natural resources, reduces the use of landfill space, prevents environmental pollution and harm to the human body $[5,6,14]$. However, most of the CRT waste glass could not be recycled into new glass because of the different chemical compositions, impurities, mixed colors, and high costs that very much affect the quality of the new product [15]. Hence, one of the objectives of this paper is to identify the alternative recycling techniques recommended by past studies for effectively managing waste CRT glass. Literature shows that one of the most effective ways is to crush the waste CRT glass and use it as fine aggregate in mortar or concrete production, as it can prevent the immobilization of heavy metals ( $\mathrm{Pb}, \mathrm{Sr}, \mathrm{Ba}$, etc.) in the surroundings. Further, the foremost objective is to review the effects of using CRT glass as a complete or partial replacement of natural sand on the properties of mortar and concrete in the aspects of workability, density, and compressive strength.

\section{Recycling techniques}

The hazardous waste CRT glass should not be directly sent to the disposal areas before being given proper treatment. According to Yoshida et al. [2], in the Philippines, only one facility was provided for processing the CRT waste. Meanwhile, in Indonesia and Vietnam, the CRT 
waste was wrongly disposed of together with the municipal solid waste. Compared to the recycling methods in Japan, the CRT unit is detached from any other components manually, so the exposed CRT is able to ventilate to remove the vacuum. After that, it is sold to the glass factory [2]. As shown in Table 1, various past studies have been conducted to determine the techniques for recycling waste CRT glass. There are eight different recycling techniques, most of which aim to remove the lead $(\mathrm{Pb})$ elements from the CRT glass. The presence of lead $(\mathrm{Pb})$ metals in the inner glass of CRTs impedes recycling of this waste. The $\mathrm{Pb}$ metals that have been extracted from the CRT glass either through lead smelting, mechanical activation, chloride volatilization process, or etc., can be used as the raw material for crystal products and fluorescent tubes, which offer an improvement in the properties of the product and save a lot of $\mathrm{Pb}$ resources. Meanwhile, the $\mathrm{CRT}$ glass that is freed from $\mathrm{Pb}$ metals can be used to make high-grade products such as glass foams, beads, containers, and glass windows $[16,17]$.

A review of past studies also claimed that CRT glass, both treated (lead-free) and untreated, has the potential to be used as fine aggregate in the production of mortar and concrete $[10,18-22]$. The presence of lead $(\mathrm{Pb})$ in untreated CRT glass is very effective in acting as a shielding material for X-rays and gamma rays. Ling et al. [11] have crushed the CRT funnel glass (treated and untreated) to a size less than $2.36 \mathrm{~mm}$ for use as fine aggregate in mortar, with the aim of shielding the surroundings from X-ray radiation. The results show the ability of hardened mortar with CRT glass aggregate as radiation-shielding since it can withstand the high-level of X-ray energy [23]. similar to the research conducted by Ismail et al. [24] that used $\mathrm{Pb}$ metals in concrete production as shielding materials for X-rays and gamma rays. Besides, several studies have proven that CRT waste glass that was crushed to a specific size is an effective replacement material for natural sand in either mortar or concrete production [18-28].

Table 1. Recycling techniques of waste CRT glass.

\begin{tabular}{|c|c|c|}
\hline Recycling technique & Description & References \\
\hline Smelting process & Extracting $\mathrm{Pb}$ elements & {$[16,29,30]$} \\
\hline Crushing to certain size below $5 \mathrm{~mm}$ & $\begin{array}{l}\text { Replacing natural sand in production of mortar } \\
\text { and concrete }\end{array}$ & {$[7,11,22,27,31]$} \\
\hline Self-propagating process & $\begin{array}{l}\text { Produce a lead-free product by removing the } \\
\mathrm{Pb} \text { element }\end{array}$ & {$[32]$} \\
\hline Mechanical activation & Extracting $\mathrm{Pb}$ element & {$[16,17,33]$} \\
\hline Washed with nitric acid & $\begin{array}{l}\mathrm{Pb} \text { removal and then use as fine aggregate in } \\
\text { concrete and mortar production }\end{array}$ & {$[9,21,23,31,34]$} \\
\hline Thermal reduction with metallic iron & Extracting $\mathrm{Pb}$ element & {$[16,35]$} \\
\hline $\begin{array}{l}\text { Chloride volatilization process } \& \text { acid- } \\
\text { leaching process }\end{array}$ & Extracting $\mathrm{Pb}$ element & {$[36,37]$} \\
\hline Alkaline leaching ( $\mathrm{S}$ and $\mathrm{NaS}$ ) & Extraction the $\mathrm{Si}$ and $\mathrm{Pb}$ elements & {$[38]$} \\
\hline
\end{tabular}

\section{Properties of concrete and mortar with CRT glass}

Recycling of CRT waste glass in mortar and concrete as fine aggregates has been examined by many scholars and has been determined as an effective way of preventing the immobilization of heavy metals in the environment. Therefore, the following paragraphs review the effects of using CRT glass as fine aggregates on the performance of mortar and concrete, in terms of workability, density, and compressive strength compared to the specimens with natural aggregates. 


\subsection{Usability}

The workability aspect is indicated by the state of the concrete or mortar mixture, whether it is easy or hard to mix, handle, and compact. It can be assessed by measuring the slump or flow values of fresh concrete [39]. The results of past studies reveal that the workability of the mixture containing CRT glass as fine aggregates is influenced by various factors which are the level of replacement, particle sizes, shapes, and types of admixtures, as tabulated in Table 2.

Table 2. The effect of using CRT glass as fine aggregates on the workability aspect

\begin{tabular}{|c|c|c|c|c|c|c|}
\hline Year & Types & Size & $\begin{array}{l}\text { Content } \\
(\%)\end{array}$ & $\begin{array}{l}\text { Increase of } \\
\text { workability }\end{array}$ & Finding & Reference \\
\hline 2011 & $\begin{array}{l}\text { Panel and } \\
\text { treated funnel }\end{array}$ & $\begin{array}{c}0.15 \text { to } \\
2.36 \mathrm{~mm}\end{array}$ & $\begin{array}{l}25,50 \\
75,100\end{array}$ & Yes & $\begin{array}{l}\text { Flow values increase as increasing } \\
\text { glass content }\end{array}$ & [19] \\
\hline 2012 & Panel & $\begin{array}{l}0.15 \text { to } \\
0.50 \mathrm{~mm}\end{array}$ & 20,40 & No & $\begin{array}{l}\text { Slump flow decreased as increasing } \\
\text { glass content }\end{array}$ & {$[10]$} \\
\hline 2012 & $\begin{array}{l}\text { Treated and } \\
\text { untreated } \\
\text { funnel }\end{array}$ & $\begin{array}{c}0.15 \text { to } \\
4.75 \mathrm{~mm}\end{array}$ & 50,100 & Yes & $\begin{array}{l}\text { Mixture with CRT glass has flow } \\
\text { value higher than with beverage glass }\end{array}$ & {$[21]$} \\
\hline 2013 & $\begin{array}{l}\text { Panel and } \\
\text { funnel }\end{array}$ & $\begin{array}{l}0.08 \text { to } 5 \\
\mathrm{~mm}\end{array}$ & $\begin{array}{l}10,20 \\
30\end{array}$ & No & $\begin{array}{l}\text { Slump value decreased as increasing } \\
\text { content of glass }\end{array}$ & {$[24]$} \\
\hline 2013 & Treated funnel & $\begin{array}{l}600 \mu \mathrm{m} \\
1.18,2.36 \\
5.00 \mathrm{~mm}\end{array}$ & 100 & Yes & $\begin{array}{l}\text { Fluidity reduced as decreasing of glass } \\
\text { particle size }\end{array}$ & {$[40]$} \\
\hline 2013 & Treated funnel & $\begin{array}{l}0.15 \text { to } \\
2.36 \mathrm{~mm}\end{array}$ & $\begin{array}{l}25,50 \\
75\end{array}$ & Yes & $\begin{array}{l}\text { Reduced segregation and bleeding, } \\
\text { mixture more consistent and } \\
\text { homogenous }\end{array}$ & [9] \\
\hline 2013 & Funnel & $\begin{array}{c}0.15 \text { to } \\
0.75 \mathrm{~mm}\end{array}$ & 20,40 & No & $\begin{array}{l}\text { Addition of limestone powder can } \\
\text { increase workability }\end{array}$ & {$[7]$} \\
\hline 2013 & Panel & $\begin{array}{l}\text { Less than } \\
500 \mu \mathrm{m}\end{array}$ & $5,10,20$ & No & $\begin{array}{l}\text { Addition of SP can increase } \\
\text { workability }\end{array}$ & {$[28]$} \\
\hline 2013 & Funnel & $\begin{array}{l}0.15 \text { to } \\
4.75 \mathrm{~mm}\end{array}$ & $\begin{array}{l}25,50 \\
\quad 75\end{array}$ & Yes & $\begin{array}{l}\text { Sample using FA as mineral admixture } \\
\text { has higher slump than GGBFS }\end{array}$ & [27] \\
\hline 2017 & $\begin{array}{l}\text { Treated and } \\
\text { untreated } \\
\text { funnel }\end{array}$ & $\begin{array}{l}0.15 \text { to } \\
4.75 \mathrm{~mm}\end{array}$ & $\begin{array}{l}25,50 \\
\quad 75\end{array}$ & Yes & $\begin{array}{l}\text { Lead }(\mathrm{Pb}) \text { content decrease the slump } \\
\text { flow }\end{array}$ & {$[41]$} \\
\hline 2019 & Funnel & $\begin{array}{l}0.15 \text { to } \\
4.75 \mathrm{~mm}\end{array}$ & $5,15,25$ & No & $\begin{array}{l}\text { Angularity, sharp and unrounded } \\
\text { edges of CRT glass after crushing } \\
\text { process generates high friction }\end{array}$ & [31] \\
\hline 2020 & Treated funnel & $1.18 \mathrm{~mm}$ & $\begin{array}{l}25,50 \\
75,100\end{array}$ & No & $\begin{array}{l}\text { Slump value decreased with increasing } \\
\text { replacement rate }\end{array}$ & {$[42]$} \\
\hline
\end{tabular}

Several past studies claimed that the increasing replacement level of CRT glass as a fine aggregate led to an increase in slump values of concrete or mortar. Ling and Poon [19] claimed that the increasing replacement level of CRT glass would increase the flow values. By maintaining a constant water-cement $(\mathrm{w} / \mathrm{c})$ ratio of 0.45 , the flow values increased $(120 \mathrm{~mm}$ to $190 \mathrm{~mm}$ ) with the increasing replacement level of CRT glass (0\% to 100\%). A year later, Ling and Poon [21] again indicated that the increase in glass content would increase the flow values. A similar observation was recorded in the next year by Zhao et al. [9,27]. Results [27] show that the loss rate of slump flow for $25 \%$ replacement was higher than $75 \%$ replacement, at $33.33 \%$, and $7.95 \%$ replacement, respectively. While the authors [9] noticed the concrete specimens containing $25 \%, 50 \%$, and $70 \%$ CRT glass sand obtained a much higher slump value 
of $85 \mathrm{~mm}, 120 \mathrm{~mm}$, and $135 \mathrm{~mm}$, respectively, than control specimens of $40 \mathrm{~mm}$. They [9,21] $[19,27]$ suggest that the improvement in workability of the mixture with the increasing content of CRT glass is because the glass has a smooth surface and lower water absorption compared to sand. However, Sua-iam and Makul [10] observed a decreasing slump value with an increasing replacement level of CRT glass. Similar findings were obtained in the research done by Romero et al. [20], Maschio et al. [28], and Sua-iam and Makul [7]. According to them, the reduction may be caused by the angular or irregular particle shape of crushed CRT glass. It creates a stronger bonding between the aggregates and cement particles, which leads to a lower fluidity of the mixture and increases the water demand for obtaining a workable mixture. It can be seen from the results obtained by Sua-iam and Makul [7,10], where the slump flow values decrease with the increasing replacement of natural sand with CRT glass at 20\% and $40 \%$ levels. It is shown that the slump flow of the SCC control specimen was $350 \mathrm{~mm}$, while the flow values of SCC specimens containing 20\% and 40\% CRT glass were $340 \mathrm{~mm}$ and $330 \mathrm{~mm}$, respectively. Besides that, Maschio et al. [28] reported that even in the case of lower replacement levels, at only $10 \%$ and $20 \%$, the workability of the CRT glass mortar mixture is much lower than the control specimens.

Since 1998, it has been recognized that the reduction of aggregate size can significantly increase the water demand for obtaining good workability [39]. It had been confirmed by the research made by Sua-iam and Makul [7,10] and Maschio et al. [28]. They claimed that using CRT glass with a particle size between 0.15 to $0.75 \mathrm{~mm}$ and a size less than $500 \mathrm{~m}$, replacing the river sand at a size less than $5 \mathrm{~mm}$ shows a reduction in slump value. Besides that, Ling and Poon [40] examined the effect of different glass particle sizes on the fluidity of mortar mixtures. The fluidity of the mortar mixtures gradually increases with the size of the glass particles. Therefore, mortar specimens containing 100\% CRT glass with a size of less than 600 $\mathrm{m}$ have the lowest fluidity compared to other sizes of $1.18 \mathrm{~mm}, 2.36 \mathrm{~mm}$, and $5 \mathrm{~mm}$. The authors [40] state that the finer particle size has a larger surface area compared to coarser glass, causing more water to be required to envelop the solid particles. According to the research conducted by Ling and Poon [21], Zhao et al. [27], and Zhao and Poon [41], they observed that the higher fineness modulus of CRT glass aggregates yields a mixture with good workability. In addition, they crushed and sieved the CRT glass to a size range between 0.15 to $4.75 \mathrm{~mm}$, and their size distribution is approximately the same as river sand. Then it showed that the mixture with CRT glass as a fine aggregate has a higher slump value compared to the mixture with natural aggregates. It may be due to the glass properties that it has a smooth surface and very low water absorption. Furthermore, it is to be noted from the study conducted by Zhao et al. [9] that the inclusion of CRT glass with a size between $0.15 \mathrm{~mm}$ and $2.36 \mathrm{~mm}$ reduces the impacts of segregation and bleeding of the concrete specimens. These have resulted in the improvement of the consistency and homogeneity of the concrete specimens.

The type of mineral admixtures used can also affect the workability of the mixture. According to Sua-iam and Makul [7], adding limestone powder can significantly improve workability by increasing the flowability and viscosity of SCC mixtures. This is because of the properties of limestone powder that has a finer particle size and spherical shape, resulting in improved particle packing. Meanwhile, Zhao et al. [27] observed that the addition of fly ash (FA) in mortar specimens containing CRT glass has shown a greater slump flow diameter than the specimens with ground granulated blast furnace slag (GGBFS) as the mineral admixture. It could be attributed to the spherical shape of FA, causing a reduction in friction between the 
aggregate and cement paste interface [39]. Besides that, the use of superplasticizer (SP) as the water reducer agent also showed an increase in workability. As recommended by Maschio et al. [28], the addition of SP is advantageous to the rheological behavior and residual porosity of mortar specimens. Other than that, a recent study by Zhao and Poon [41] indicated that the use of untreated CRT funnel glass, which contains lead $(\mathrm{Pb})$ metals, can retard the hydration process as the mortar samples containing untreated crushed CRT funnel glass have lower slump loss rates than those with treated (lead-free) CRT glass. It was observed at the same replacement level of $50 \%$ and $75 \%$, as the loss rates of slump flow for the mortar specimens with the untreated funnel and the treated funnel were $7.95 \%, 18.31 \%$, and $10.98 \%, 22.08 \%$, respectively.

\subsection{Density}

Past studies stated that the use of CRT glass as fine aggregates had increased the density of hardened mortar and concrete. It is because the CRT glass has a higher density than natural aggregates, specifically river sand. Regardless of the Pb content of the CRT glass, Ling and Poon [40,43,44], Romero et al. [20], Zhao et al. [9], and Zhao and Poon [41] found that the density of CRT glass is between 2.98 and $3.10 \mathrm{~g} / \mathrm{cm} 3$, while river sand is between 2.49 and $2.62 \mathrm{~g} / \mathrm{cm} 3$. Thus, the increasing content of CRT glass as fine aggregate causes a higher density of hardened mortar or concrete. Romero et al. [20] claimed that the density increased directly with the increase in percentage replacement. Zhao et al. [9] reported the increased density of hardened concrete at levels of 25\% (2941 kg/m3), 50\% $(2967 \mathrm{~kg} / \mathrm{m} 3)$, and 75\% was 2992 $\mathrm{kg} / \mathrm{m} 3$, which showed an increase of $0.93 \%, 1.82 \%$, and $2.68 \%$, respectively. Besides that, a complete replacement $(100 \%)$ of sand with CRT glass has shown an increase in density of about 11\% compared to control samples, as recorded by Ling and Poon [40].

Heavyweight concrete is desirable in other types of applications, such as radiation shielding $[11,43,45,46]$. However, this has become a discouraging factor in some applications as it causes an additional dead weight in building construction [6]. There are some studies that have been conducted that show that the density of hardened concrete and mortar containing CRT glass can be reduced by decreasing the glass particle size. Ling and Poon [40] pointed out that the milling of treated funnel glass, which undergoes an acid-treatment process into a finer size, can reduce its density as the higher amounts of $\mathrm{Pb}$ elements can be eliminated. Therefore, it is clearly shown that the high density of CRT glass can also be related to the content of $\mathrm{Pb}$ metals, mainly in the funnel part of CRT glass. Ling et al. [11] did a study on the significant effect of $\mathrm{Pb}$ elements in the CRT funnel glass on the mortar density. It was observed that the density increased with the presence of $\mathrm{Pb}$ in the mortar. The density of mortar specimens containing 100\% untreated funnel glass and another specimen containing $100 \%$ treated funnel glass (lead-free), both as fine aggregates, shows an increased density of about $14.6 \%$ and $11.2 \%$, respectively. It shows that the removal of lead (treated funnel) lowers the density of the mortar. A year later, Ling and Poon [40] reported a similar observation, claiming that the higher the presence of lead metals in CRT glass, the higher the mortar density.goes with the concrete specimens containing panels of CRT glass. As a result of the lower amount of lead (panel CRT glass) compared to funnel CRT glass, the density of hardened concrete panel glass was less than funnel glass, which was about $2790 \mathrm{~kg} / \mathrm{m} 3$ and $3000 \mathrm{~kg} / \mathrm{m} 3$, respectively [26]. According to previous research, the relative density of untreated funnel CRT glass (containing $\mathrm{Pb}$ ) ranges between 3.00 and $3.10 \mathrm{~g} / \mathrm{cm} 3$, whereas treated funnel CRT glass is $2.99 \mathrm{~g} / \mathrm{cm} 3[26,40,41,45]$. 


\subsection{Compressive strength}

The compressive strength of hardened mortar and concrete is the essential mechanical aspect compared to others. Past studies claimed that replacing the natural sand with CRT glass had increased the compressive strength compared to control specimens $[20,27,41,47,48]$. On the other hand, there are also some studies reporting differing results [22,40-44,49]. Besides depending on the mix design, several researchers indicated there are several parameters such as replacement level, particle size, lead content, etc. that can affect the compressive strength of hardened mortar and concrete. Table 3 shows a summary of past studies on the effect of using CRT glass as a fine aggregate on the aspect of compressive strength of concrete and mortar.

Table 3. The effect of using CRT glass as fine aggregates on the aspect of compressive strength

\begin{tabular}{|c|c|c|c|c|c|c|}
\hline Year & Types & Size & $\begin{array}{l}\text { Content } \\
(\%)\end{array}$ & $\begin{array}{l}\text { Increase of } \\
\text { compressive } \\
\text { strength }\end{array}$ & Finding & Reference \\
\hline 2012 & $\begin{array}{l}\text { Treated and } \\
\text { untreated } \\
\text { funnel }\end{array}$ & $\begin{array}{c}0.15 \text { to } 2.36 \\
\mathrm{~mm}\end{array}$ & $\begin{array}{l}25,50 \\
75,100\end{array}$ & No & $\begin{array}{l}\text { Presence of lead }(\mathrm{Pb}) \text { in the glass does } \\
\text { not give any significant impact on } \\
\text { strength }\end{array}$ & [11] \\
\hline 2012 & $\begin{array}{l}\text { Treated and } \\
\text { untreated } \\
\text { funnel }\end{array}$ & $\begin{array}{c}0.15 \text { to } 4.75 \\
\mathrm{~mm}\end{array}$ & $\begin{array}{l}25,50 \\
75,100\end{array}$ & No & $\begin{array}{l}\text { Presence of lead }(\mathrm{Pb}) \text { in the glass does } \\
\text { not give any significant impact on } \\
\text { strength }\end{array}$ & [44] \\
\hline 2013 & $\begin{array}{l}\text { Treated } \\
\text { funnel }\end{array}$ & $\begin{array}{l}1.18 \mathrm{~mm} \\
\text { and } 600 \mu \mathrm{m}\end{array}$ & 100 & No & $\begin{array}{l}\text { Strength of CRT glass mortars was } \\
\text { comparable to beverage glass mortars }\end{array}$ & [40] \\
\hline 2013 & $\begin{array}{l}\text { Panel and } \\
\text { funnel }\end{array}$ & $\begin{array}{l}0.08 \mathrm{~mm} \text { to } \\
5.00 \mathrm{~mm}\end{array}$ & $\begin{array}{l}10,20 \\
30\end{array}$ & Yes & $\begin{array}{l}\text { Strength increases as increase of the } \\
\text { replacement level }\end{array}$ & [20] \\
\hline 2013 & Funnel & $\begin{array}{c}0.15 \text { to } 4.75 \\
\mathrm{~mm}\end{array}$ & $\begin{array}{l}25,50 \\
\quad 75\end{array}$ & Yes & $\begin{array}{l}\text { Addition of GGBFS gives higher } \\
\text { strength than FA }\end{array}$ & [27] \\
\hline 2013 & Funnel & $\begin{array}{c}0.15 \text { to } 0.75 \\
\mathrm{~mm}\end{array}$ & 20,40 & No & $\begin{array}{l}\text { Addition of limestone powder increased } \\
\text { strength }\end{array}$ & [7] \\
\hline 2013 & Panel & $\begin{array}{l}\text { Less than } \\
500 \mu \mathrm{m}\end{array}$ & $5,10,20$ & Yes & $\begin{array}{l}\text { Rapid increase of strength with addition } \\
\text { of } 1 \% \text { SP }\end{array}$ & [28] \\
\hline 2014 & $\begin{array}{l}\text { Treated and } \\
\text { untreated } \\
\text { funnel }\end{array}$ & $\begin{array}{c}0.15 \text { to } 4.75 \\
\mathrm{~mm}\end{array}$ & 50,100 & No & $\begin{array}{l}\text { Presence of lead }(\mathrm{Pb}) \text { in the glass does } \\
\text { not give any significant impact on } \\
\text { strength }\end{array}$ & [43] \\
\hline 2014 & $\begin{array}{l}\text { Treated } \\
\text { funnel }\end{array}$ & $\begin{array}{c}0.15 \text { to } 4.75 \\
\mathrm{~mm}\end{array}$ & 50,100 & No & $\begin{array}{l}\text { Strength reduces with increase of } \\
\text { replacement level }\end{array}$ & [22] \\
\hline 2015 & Panel & $80 \mu \mathrm{m}$ & 80,100 & Yes & $\begin{array}{l}\text { Increase strength by using smaller glass } \\
\text { particle size and addition of fly ash }\end{array}$ & [47] \\
\hline 2017 & Funnel & $\begin{array}{c}0.15 \text { to } 4.75 \\
\mathrm{~mm}\end{array}$ & 100 & No & $\begin{array}{l}\text { Addition of incinerated sewerage sludge } \\
\text { ash (ISSA) have decreased the strength } \\
\text { compared to GGBFS and FA }\end{array}$ & [49] \\
\hline 2017 & $\begin{array}{l}\text { Treated and } \\
\text { untreated } \\
\text { funnel }\end{array}$ & $\begin{array}{c}0.15 \text { to } 4.75 \\
\mathrm{~mm}\end{array}$ & $\begin{array}{l}25,50 \\
75\end{array}$ & Yes & $\begin{array}{l}\text { Strength increases as increase of } \\
\text { replacement level and presence of } \mathrm{Pb}\end{array}$ & [41] \\
\hline 2019 & Funnel & $\begin{array}{l}015 \text { to } 4.75 \\
\mathrm{~mm}\end{array}$ & $5,15,25$ & No & $\begin{array}{l}\text { Strength decreases due to weaker } \\
\text { interfacial transition zone }\end{array}$ & [31] \\
\hline 2020 & Funnel & $\begin{array}{c}0.15 \text { to } 4.75 \\
\mathrm{~mm}\end{array}$ & $\begin{array}{l}5,10 \\
15,20\end{array}$ & Yes & $\begin{array}{l}\text { Strength increases with increase of } \\
\text { replacement level }\end{array}$ & [48] \\
\hline 2020 & $\begin{array}{l}\text { Treated } \\
\text { funnel }\end{array}$ & $1.18 \mathrm{~mm}$ & $\begin{array}{l}25,50 \\
75,100\end{array}$ & No & $\begin{array}{l}\text { Addition of silica fume increased } \\
\text { strength }\end{array}$ & [42] \\
\hline 2021 & Funnel & $\begin{array}{l}0.15 \text { to } 4.75 \\
\mathrm{~mm}\end{array}$ & 50,100 & No & $\begin{array}{l}\text { Strength decreases with increase of } \\
\text { replacement level }\end{array}$ & [46] \\
\hline
\end{tabular}




\subsubsection{Effect of replacement level of CRT glass}

The compressive strength of either concrete or mortar is affected by the amount of CRT glass replacing the natural sand. In 2012, the research done by Ling et al. [11] and Ling and Poon [44] showed that the compressive strength reduced with the increasing replacement level of CRT glass as fine aggregates, at $25 \%, 50 \%, 75 \%$, and $100 \%$ by volume of sand. They $[11,31,44,46]$ suggested that the decrease in mortar strength is because of the increase in weak points. The physical features of CRT glass that have a smooth and plane surface have created a weak point within the glass as aggregate and cement paste. The same findings were also reported by other researchers [50-53] using different types of glass (window, beverage, container glass, etc.). A year later, Zhao et al. [9] also reported similar findings as the reduction rates of $25 \%, 50 \%$, and $75 \%$ of funnel glass as a fine aggregate were $11.38 \%, 18.19 \%$, and $22.65 \%$, respectively.

The SEM observation made by Ling and Poon [22] in 2014 supported the cause of strength reduction due to the glass smooth surface. The microstructure of the crushed specimen containing CRT glass reveals that the bonding between the glass aggregates and cement paste is weak compared to specimens using natural sand, which has a rougher surface than glass [42]. Besides, Ling and Poon [22] reported a decrease in the compressive strength with the increasing replacement level of CRT glass, as the replacement levels of $50 \%$ and $100 \%$ have lower strengths than normal concrete, 68.3 MPa, 55.6 MPa, and 68.6 MPa, respectively. The reduction of compressive strength can be overcome by using an optimum ratio of aggregate to cement and adopting a correct method of casting [43].

However, there are also some studies that indicate that the replacement of natural sand with CRT glass has increased the compressive strength of hardened mortar and concrete, as well as the replacement level is directly proportional to the compressive strength [20,27]. Romero et al. [20] assured that the fine aggregate replacement by crushed CRT glass has met and exceeded the compressive strength of control specimens, by $5.5 \%, 19.5 \%$, and $13.2 \%$ at the level of $10 \%, 20 \%$, and $30 \%$ replacement, respectively. The highest compressive strength is obtained at $20 \%$ replacement. Meanwhile, for the higher percentage replacement of $25 \%$, $50 \%$ and $75 \%$, Zhao et al. [27] reported the enhancement of compressive strength for each of the replacement levels. In addition, a recent study that had been conducted by Zhao and Poon [41] also claimed the same findings.

\subsubsection{Effect of particle size on the particle size of CRT glass}

The compressive strength of mortar and concrete using CRT glass as aggregate is greatly influenced by the glass particle size. Maschio et al. [28] replaced 10\% of the river sand size less than $4.75 \mathrm{~mm}$ with CRT glass milled to less than $500 \mathrm{~m}$ in 2013.The compressive strength of hardened mortar improved from $45 \mathrm{MPa}$ after 3 days of curing to $60 \mathrm{MPa}$ after 7 days, 83 MPa after 28 days, $100 \mathrm{MPa}$ after 90 days, and $105 \mathrm{MPa}$ after 180 days compared to control specimens of $50 \mathrm{MPa}, 66 \mathrm{MPa}, 87 \mathrm{MPa}, 97 \mathrm{MPa}$, and $100 \mathrm{MPa}$, respectively. Therefore, they [28] claim that the use of smaller sizes of CRT glass in replacing the natural aggregates can increase the compressive strength. In the next 2 years, a similar finding was also recorded by Walczak et al. [47]. They [47] examined the compressive strength of mortar containing CRT glass cullet that was crushed to a size around $80 \mu \mathrm{m}$ with a Blaine fineness of $2000 \mathrm{~cm}^{2} / \mathrm{g}$. The results indicated an increase in compressive strength of $16 \%$ compared to control samples. The 
improvement in compressive strength might be because of the pozzolanic activity that may develop from the use of CRT glass that was ground or crushed to a few tenths of a micrometres or powder and also might be due to the high concentration of silica in the CRT glass $[7,22,28,47]$.

According to the SEM observation done by Maschio et al. [28], there is the presence of silicate hydrated crystal clusters on the mortar samples which contain CRT glass with a size less than $75 \mathrm{~m}$. Thus, it indicates that the use of specific sizes of CRT glass that are less than $75 \mathrm{~m}$ possesses a pozzolanic reaction, as the silicate hydrated crystal clusters are developed only around the finer glass particles. The pores that exist in the cement and glass aggregate matrix may be occupied by the silicate hydrated crystals during the curing period, which then interlocks the surrounding material, resulting in densely packed structures and a higher compressive strength [28]. In addition, they [28] also observed that at the interface of glass particles and the cementitious matrix is explicit with no pores. The findings were also consistent with the previous studies that used different types of waste glass as fine aggregates, such as fluorescent lamps, containers, beads, and bottles of glass [54-56]. Shao et al. [54] and Raju and Kumar [57] pointed out that by crushing the glass to a size smaller than $38 \mathrm{~m}$ and 45 $\mathrm{m}$, respectively, is an excellent filler with high pozzolanic reactivity which has the potential to replace a portion of the cement content.

However, there are also studies reporting that using a larger size of CRT glass as a fine aggregate can increase the compressive strength. They [40] recommend that the use of a larger particle size of CRT glass will provide a wider continuous particle size distribution in the mortar, resulting in better particle packing that improves the compressive strength. Ling and Poon [40] studied the effects of several particle sizes of CRT glass on the aspect of compressive strength. They [40] observed the increase of glass size from $600 \mu \mathrm{m}$ to $1.18 \mathrm{~mm}, 2.36 \mathrm{~mm}$, and $5 \mathrm{~mm}$, showing a higher increment of compressive strength around $2.5 \%, 10.8 \%$ and $30.8 \%$, respectively.

\subsubsection{Effect of admixture and lead content}

As widely reported previously, the addition of mineral admixtures in concrete and mortar mixtures may increase the compressive strength. In 2013, Zhao et al. [27] aimed to increase the compressive strength of hardened mortar using CRT funnel glass as a fine aggregate by replacing $25 \%$ of the OPC with FA and GGBFS. The results show that the compressive strength of mortar specimens with the addition of GGBFS is higher by $23 \%$ than mortar specimens with FA at the curing period of 28 days. But, Taha and Nounu [58] claim that the addition of $10 \%$ metakaolin $(\mathrm{MK})$ is more useful in increasing the compressive strength of glass concrete compared to the specimens that used 60\% GGBFS and 20\% glass powder. However, in 2015, Walczak et al. [47] claimed that the mortar specimens with a $100 \%$ replacement of natural sand with $20 \% \mathrm{FA}$ and the remaining $80 \%$ replaced by crushed CRT glass, had shown a higher compressive strength than control specimens. The improvement of compressive strength ensued as a result of the pozzolanic activity, filler role and speeding up of the cement hydration process. Other than that, a recent study by Li et al. [49] reported that the use of incinerated sewerage sludge ash (ISSA) in mortar mixtures containing CRT glass has decreased the compressive strength with the increasing content of ISSA. The contrasted findings may be due to the properties of ISSA that cannot counterbalance the low pozzolanic activity, thus leading to lower compressive strength compared to samples using FA and GGBFS as admixtures. 
Sua-iam and Makul [7] investigate the influence of adding 5\%,10\%, and $15 \%$ of limestone powder to the compressive strength of self-compacting concrete (SCC) mixtures with CRT glass (20\% and 40\%) as fine aggregate. The optimum SCC mixtures were recorded on the specimens with 5\% limestone powder and 20\% CRT glass, which showed the highest compressive strength among others, especially control specimens. The addition of fine limestone improves particle packing by broadening the grain-size distribution. Through the SEM observation on the fracture surface of the SCC specimens, Sua-iam and Makul [7] observed that crushed CRT glass was surrounded by limestone powder gel. They suggest that the limestone powder gel prevents the edges of glass from colliding with each other, which then causes the improvement of compressive strength. Meanwhile, Maschio et al. [28] reported that the adding of water reducers at levels of $1 \%$ and $2 \%$ of cement content to the mortar mixtures containing CRT glass has shown enhancement of compressive strength at every curing age of $3,7,28,90$, and 180 days. The use of water reducing agents allows for a lower w/c ratio, which improves the compressive strength of hardened mortar and concrete [28,39$43,59]$.

\subsubsection{Effect of treated or untreated CRT glass}

Some studies reported that there was no significant effect of the lead $(\mathrm{Pb})$ content of the CRT glass on the aspect of compressive strength. The results from the studies conducted by Ling et al. [11] and Ling and Poon $[43,44]$ reported that there was not much difference in compressive strength between mixtures containing untreated and treated CRT funnel glass, depending on whether the funnel glass was acid washed or unwashed. However, a recent study conducted by Zhao and Poon [41] claimed that the presence and increasing content of lead $(\mathrm{Pb})$ in mortar results in higher compressive strength than lead-free mortar. Based on their [41] results, the mortar mixtures containing untreated CRT funnel glass (unwashed) at replacement levels of $25 \%, 50 \%$, and $75 \%$ show a higher increase in compressive strength of $8.17 \%, 9.53 \%$, and $10.08 \%$, in comparison to the treated CRT funnel glass that has been washed with nitric acid.

\section{Conclusions}

Extensive past research has identified several recycling techniques for managing the increasing amount of waste CRT glass, and based on the review of past studies, the present study discovers that the difference in chemical composition, physical, and mechanical features of CRT glass as fine aggregates are affecting the properties of concrete or mortar. Several conclusions from the review of past studies are listed below:

i. The physical properties of glass that have a smooth surface, are impermeable and have lower water absorption than river sand have increased the workability of the mixture.

ii. However, some researchers also reported a reduction in workability due to the decreasing particle size, irregular particle shape, and presence of $\mathrm{Pb}$ metals in the CRT glass.

iii. CRT glass has a higher relative density than river sand, which is in the range between 2.99 to $3.10 \mathrm{~g} / \mathrm{cm}^{3}$ and 2.49 to $2.62 \mathrm{~g} / \mathrm{cm}^{3}$, respectively. Thus, most of the past studies reported the increase of mortar and concrete density. One of the contributors is the lead $(\mathrm{Pb})$ content in the CRT glass. 
iv. The majority of the researchers claimed that the physical feature of glass with a smooth surface caused the connection between aggregate and cement to become weak, resulting in a reduction of compressive strength.

v. Some researchers reported that crushing the glass to a few tenths of a micrometers or powder can increase the strength as it shows pozzolanic activity since the CRT glass contains a high concentration of silica ( $\mathrm{Si}$ ) elements. But some researchers said otherwise. The use of a larger glass particle size offers better particle packing.

vi. It is worth mentioning here that there is more than one parameter that can contribute to a better performance of concrete and mortar using CRT glass as fine aggregates, which are the percentage replacement, particle size, $\mathrm{Pb}$ content, types of admixtures and method of casting.

\section{Acknowledgments}

Author express gratitude to the National University of Malaysia (UKM) for administration support, which made this study possible.

\section{Conflicts of Interest}

The authors declare no conflict of interest.

\section{References}

[1] Singh N.; Wang J.; Li J. (2016). Waste Cathode Rays Tube: An Assessment of Global Demand for Processing. Procedia Environmental Science, 31, 465-474. https://doi.org/10.1016/j.proenv.2016.02.050

[2] Yoshida A.; Terazono A.; Ballesteros F.C. (2016). Resources , Conservation and Recycling Ewaste recycling processes in Indonesia, the Philippines, and Vietnam : A case study of cathode ray tube TVs and monitors. Resources, Conservation Recycling, 106, 48-58. https://doi.org/10.1016/j.resconrec.2015.10.020.

[3] Environmental Investigation Agency (EIA) (2013). Illicit trade in electrical and electronic waste (e-waste) from the world to the region. In: Aldo Lale-Demoz, Director, DO, and Gary Lewis, the former UNODC Regional Representative R (ed) Transnational organized crime thread assessmenet - East Asia and the Pacific. United Nations Office on Drugs and Crime (UNODC), United States, pp 101-111.

[4] Shaw Environmental I. (2013). An analysis of the demand for CRT glass processing in the US. United States.

[5] Xu Q.; Li G.; He W. (2012). Cathode ray tube (CRT) recycling : Current capabilities in China and research progress. Waste Management, 32, 1566-1574. https://doi.org/10.1016/j.wasman.2012.03.009.

[6] Rashad A.M. (2015). Recycled cathode ray tube and liquid crystal display glass as fine aggregate replacement in cementitious materials. Construction and Building Materials, 93, 1236-1248. https://doi.org/10.1016/j.conbuildmat.2015.05.004.

[7] Sua-iam G.; Makul N. (2013). Use of limestone powder during incorporation of Pb-containing cathode ray tube waste in self-compacting concrete. Journal of Environmental Management, 128, 931-940. https://doi.org/10.1016/j.jenvman.2013.06.031.

[8] Rocchetti L.; Beolchini F. (2014). Environmental burdens in the management of end-of-life cathode ray tubes. Waste Management, 34, 468-474. https://doi.org/10.1016/j.wasman.2013.10.031. 
[9] Zhao H.; Poon C.S.; Ling T.C. (2013). Utilizing recycled cathode ray tube funnel glass sand as river sand replacement in the high-density concrete. Journal of Cleaner Production, 51, 184-190. https://doi.org/10.1016/j.jclepro.2013.01.025.

[10] Sua-Iam G.; Makul N. (2012). Use of limestone powder to improve the properties of selfcompacting concrete produced using cathode ray tube waste as fine aggregate. Applied Mechanics and Materials, 193-194, 472-476. https://doi.org/10.4028/www.scientific.net/AMM.193194.472.

[11] Ling T-C.; Poon C.S.; Lam W. S. (2012). Utilization of recycled cathode ray tubes glass in cement mortar for X-ray radiation-shielding applications. Journal of Hazardaus Materials, 199-200, 321327. https://doi.org/10.1016/j.jhazmat.2011.11.019.

[12] Walczak P.; Małolepszy J.; Reben M.; Karol; Rzepa P.S. (2015). Utilization of waste glass in autoclaved aerated concrete. Procedia Engineering, 122, 302-309. https://doi.org/http://dx.doi.org/10.1016/j.proeng.2015.10.040.

[13] Meng W.; Wang X.; Yuan W. (2016). The recycling of leaded glass in Cathode Ray Tube (CRT). Procedia Environmental Sciences, 31, 954-960. https://doi.org/10.1016/j.proenv.2016.02.120.

[14] Bhakar V.; Agur A.; Digalwar A.K.; Sangwan K.S. (2015). Life Cycle Assessment of CRT, LCD and LED monitors. Procedia CIRP, 29, 432-437. https://doi.org/10.1016/j.procir.2015.02.003.

[15] Sikora P.; Horszczaruk E.; Rucinska T. (2015). The effect of nanosilica and titanium dioxide on the mechanical and self-cleaning properties of waste-glass cement mortar. Procedia Engineering, 108, 146-153. https://doi.org/10.1016/j.proeng.2015.06.

[16] Yu M.; Liu L. (2016). An overall Solution to Cathode-Ray Tube (CRT) glass recycling. Procedia Environmental Science, 31, 887-896. https://doi.org/10.1016/j.proenv.2016.02.106.

[17] Singh N.; Li J.; Zeng X. (2016). Solutions and challenges in recycling waste cathode-ray tubes. Journal of Cleaner Production, 133, 188-200. https://doi.org/10.1016/j.jclepro.2016.04.132.

[18] Hui Z.; Sun W, (2011). Study of properties of mortar containing cathode ray tubes (CRT) glass as replacement for river sand fine aggregate. Construction of Building Materials, 25, 4059-4064. https://doi.org/10.1016/j.conbuildmat.2011.04.043.

[19] Ling T.C.; Poon C.S. (2011). Utilization of recycled glass derived from cathode ray tube glass as fine aggregate in cement mortar. Journal of Hazardous Materials, 192, 451-456. https://doi.org/10.1016/j.jhazmat.2011.05.019.

[20] Romero D.; James J.; Mora R.; Hays C.D. (2013). Study on the mechanical and environmental properties of concrete containing cathode ray tube glass aggregate. Waste Management, 33, 16591666. https://doi.org/10.1016/j.wasman.2013.03.018.

[21] Ling T.C.; Poon C.S. (2012). A comparative study on the feasible use of recycled beverage and CRT funnel glass as fine aggregate in cement mortar. Journal of Cleaner Production, 29-30, 4652. https://doi.org/10.1016/j.jclepro.2012.02.018.

[22] Ling T.; Poon C. (2014). Use of recycled CRT funnel glass as fine aggregate in dry-mixed concrete paving blocks. Journal of Cleaner Production, 68, 209-215. https://doi.org/10.1016/j.jclepro.2013.12.084.

[23] Liu H.; Shi J.; Qu H.; Ding D. (2019). An investigation on physical , mechanical, leaching and radiation shielding behaviors of barite concrete containing recycled cathode ray tube funnel glass aggregate. Construction of Building Materials, 201, 818-827. https://doi.org/10.1016/j.conbuildmat.2018.12.221.

[24] Ismail M.P.; Masenwat N.A.; Sani S. (2012). Concrete mix design for X-and gamma shielding. International: Research and Development Seminar. Malaysia.

[25] Srivastava V.; Gautam S.P.; Agarwal V.C.; Mehta P.K. (2013). Glass wastes as coarse aggregate in concrete. Journal Environmental Nanotechnology, 312, 67-71. https://doi.org/10.13074/jent.2013.12.132059.

[26] Lee J.S.; Yoo H.M.; Park S.W. (2015). Recycling of cathode ray tube panel glasses as aggregates of concrete blocks and clay bricks. Journal of Material Cycles and Waste Management, 1-11. https://doi.org/10.1007/s10163-015-0350-6. 
[27] Zhao H.; Poon C.S.; Ling T.C. (2013). Properties of mortar prepared with recycled cathode ray tube funnel glass sand at different mineral admixture. Construction of Building Materials, 40, 951960. https://doi.org/10.1016/j.conbuildmat.2012.11.102.

[28] Maschio S.; Tonello G.; Furlani E. (2013). Recycling glass cullet from waste CRTs for the production of high strength mortars. Journal of Waste Management, 1-8. https://doi.org/10.1155/2013/102519.

[29] Nnorom I.C.; Osibanjo O.; Ogwuegbu M.O.C. (2011). Global disposal strategies for waste cathode ray tubes. Resources, Conservation and Recycling, 55, 275-290. https://doi.org/10.1016/j.resconrec.2010.10.007.

[30] Bleher D. (2014). Recycling options for waste CRT glass. Bo2W project consortium, Darmstadt, Germany.

[31] Wang J.; Guo S.; Dai Q,. (2019). Evaluation of cathode ray tube (CRT) glass concrete with/without surface treatment. Journal of Cleaner Production, 226, 85-95. https://doi.org/10.1016/j.jclepro.2019.03.300.

[32] Wang Y.; Zhu J. (2012). Preparation of lead oxide nanoparticles from cathode-ray tube funnel glass by self-propagating method. Journal of Hazardous Materials, 215-216, 90-97. https://doi.org/10.1016/j.jhazmat.2012.02.041.

[33] Yuan W.; Li J.; Zhang Q.; Saito F. (2012). Innovated application of mechanical activation to separate lead from scrap cathode ray tube funnel glass. Environmetal Science and Technology, 46, 4109-4114. https://doi.org/10.1021/es204387a.

[34] Ling T-C.; Poon C-S. (2012). Development of a method for recycling of CRT funnel glass. Environmental Technology, 33, 2531-2357. https://doi.org/http://dx.doi.org/10.1080/09593330.2012.666570.

[35] Lu X.; Shih K.; Liu C.; Wang F. (2013). Extraction of metallic lead from cathode ray tube (CRT) funnel glass by thermal reduction with metallic iron. Environmental Science and Technology, 47, 9972-9978. https://doi.org/10.1021/es401674d.

[36] Grause G.; Takahashi K.; Kameda T.; Yoshioka T. (2014). Lead removal from cathode ray tube glass by the action of calcium hydroxide and poly (vinyl chloride). Thermochimica Acta, 596, 4955. https://doi.org/10.1016/j.tca.2014.09.019.

[37] Erzat A.; Zhang F-S. (2014). Evaluation of lead recovery efficiency from waste CRT funnel glass by chlorinating volatilization process. Environmental Technology, 35, 2774-2780. https://doi.org/10.1080/09593330.2014.921731.

[38] Yao Z.; Xie Z.; Tang J. (2016). A typical e-waste - Cathode Ray Tube glass: Alkaline leaching in the sulfur-containing medium. Procedia Environmental Science, 31, 880-886. https://doi.org/10.1016/j.proenv.2016.02.104.

[39] ACI 211.4R (1998). Guide for Selecting Proportions for High-Strength Concrete with Portland Cement and Fly Ash.

[40] Ling T-C.; Poon C-S. (2013). Effects of particle size of treated CRT funnel glass on properties of cement mortar. Materials and Structures, 46, 25-34. https://doi.org/10.1617/s11527-012-9880-8.

[41] Zhao H.; Poon C.S. (2017). A comparative study on the properties of the mortar with the cathode ray tube funnel glass sand at different treatment methods. Construction of Building Materials, 148, 900-909. https://doi.org/10.1016/j.conbuildmat.2017.05.019.

[42] Wei H.; Zhou A.; Liu T. (2020). Dynamic and environmental performance of eco-friendly ultrahigh performance concrete containing waste cathode ray tube glass as a substitution of river sand. $\begin{array}{lllll}\text { Resource Conservation } & \text { and Recycling, } & 162, & \end{array}$ https://doi.org/10.1016/j.resconrec.2020.105021.

[43] Ling T-C.; Poon C-S. (2014). Use of CRT funnel glass in concrete blocks prepared with different aggregate-to-cement ratios. Green Materials, 2, 43-51. https://doi.org/10.1680/gmat.13.00013.

[44] Ling T.C.; Poon C.S. (2012). Feasible use of recycled CRT funnel glass as heavyweight fine aggregate in barite concrete. Journal of Cleaner Production, 33, 42-49. https://doi.org/10.1016/j.jclepro.2012.05.003. 
[45] Ling T-C.; Poon C.S. (2013). High temperatures properties of barite concrete with CRT funnel glass. Fire and Materials, 38, 279-289. https://doi.org/10.1002/fam.2181.

[46] Choi Y.S.; Lee S.M. (2021). Fundamental properties and radioactivity shielding performance of concrete recycled cathode ray tube waste glasses and electric arc furnace slag as aggregates. Progress in Nuclear Energy, 133, 103649. https://doi.org/10.1016/j.pnucene.2021.103649.

[47] Walczak P.; Małolepszy J.; Reben M.; Rzepa K. (2015). Mechanical properties of concrete mortar based on mixture of CRT glass cullet and fluidized fly ash. Procedia Engineering, 108, 453-458. https://doi.org/10.1016/j.proeng.2015.06.170.

[48] Hamsavathi K.; Prakash K.S.; Kavimani V. (2020). Green high strength concrete containing recycled cathode ray tube panel plastics (E-waste) as coarse aggregate in concrete beams for structural applications. Journal of Building Engineering, 30. https://doi.org/10.1016/j.jobe.2020.101192.

[49] Li J.; Guo M.; Qiang X.; Poon C.S. (2017). Recycling of incinerated sewage sludge ash and cathode ray tube funnel glass in cement mortars. Journal of Cleaner Production. https://doi.org/10.1016/j.jclepro.2017.03.116.

[50] Degirmenci N.; Yilmaz A.; Cakir O.A. (2011). Utilization of waste glass as sand replacement in cement mortar. Indian Journal of Engineering and Materials Sciences, 18, 303-308.

[51] Kumar B.N.; Kumar M. (2016). Influence of glass powder on the properties of concrete. Journal of Mechanical and Civil Engineering, 2, 36-45.

[52] Tan K.H.; Du H. (2013). Use of waste glass as sand in mortar: Part I - Fresh, mechanical and durability properties. Cement and Concrete Composites, 35, 118-126. https://doi.org/10.1016/j.cemconcomp.2012.08.028.

[53] Haider K.; Ammash; Muhammed S.; Muhammad A.H.N. (2009). Using of waste glass as fine aggregate in concrete. Journal for engineering science, 2, 206-214.

[54] Shao Y.; Lefort T.; Moras S.; Rodriguez D. (2000). Studies on concrete containing ground waste glass. Cement and Concrete Research, 30, 91-100. https://doi.org/10.1016/S00088846(99)00213-6.

[55] Kou S.C.; Xing F. (2012). The effect of recycled glass powder and reject fly ash on the mechanical properties of fibre-reinforced ultrahigh performance concrete. Advances in Materials Science and Engineering, 1-8. https://doi.org/10.1155/2012/263243.

[56] Shi C.; Wu Y.; Riefler C.; Wang H. (2005). Characteristics and pozzolanic reactivity of glass powders. Cement and Concrete Research, 35, 987-993. https://doi.org/10.1016/j.cemconres.2004.05.015

[57] Raju S.; Kumar P. R. (2014). Effect of using glass powder in concrete. International journal of innovative research in science, enginnering and technology, 3, 421-427.

[58] Taha B.; Nounu G. (2008). Properties of concrete contains mixed colour waste recycled glass as sand and cement replacement. Construction and Building Materials 22, 713-720. https://doi.org/10.1016/j.conbuildmat.2007.01.019.

[59] Mo K.H.; Alengaram U.J.; Jumaat M.Z. (2016). Bond properties of lightweight concrete - A review. Construction and Building Materials 112, 478-496. https://doi.org/10.1016/j.conbuildmat.2016.02.125.

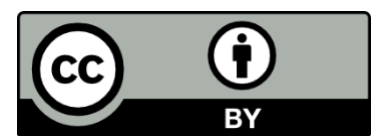

(C) 2021 by the authors. This article is an open access article distributed under the terms and conditions of the Creative Commons Attribution (CC BY) license (http://creativecommons.org/licenses/by/4.0/). 